\title{
The Consumer Rights Act 2015 and Collective Redress for Competition Law Infringements in the UK: A Class Act? ${ }^{1}$
}

\begin{abstract}
This article is the first in-depth academic discussion of the key aspects of the enhanced collective redress mechanisms introduced recently in relation to competition law infringements in the UK by the Consumer Rights Act. The legislation is a particularly significant development because of the historical and contemporary focus on the 'consumer' at the heart of competition/antitrust law and because the reforms also reflect more recent debates generally in legal practice about 'access to justice'. The article first recounts the pivotal role played by 'class actions' in US antitrust enforcement before outlining the recent debate on encouraging and facilitating private enforcement in the EU, particularly in relation to collective redress, culminating in the (anodyne) Commission Recommendation of June 2013. As the article notes, most of the collective redress mechanisms introduced across the EU Member States to date have been opt-in models, but these have been criticised for their limited impact and effectiveness, and an opt-out representative model has been introduced in some Member States and discussed in others. The article will reflect on the limited provision in the UK on collective redress in relation to competition law infringements prior to the Consumer Rights Act, in particular the limitations in the opt-in follow-on procedure under s47B of the Competition Act 1998, as demonstrated by $C A \vee J J B$. The article will then focus on the Act's provisions (and associated Tribunal rules) in relation to opt-in/opt-out collective proceedings and settlements (in both follow-on and stand-alone actions). The article will outline the new statutory provisions in sections $47 \mathrm{~B}$ and $49 \mathrm{~A}$ and B of the Competition Act 1998, for Collective Proceedings and Collective Settlements respectively. The Tribunal rules on certification will be considered, noting the potential difficulties in their practical application, before further analysis of two key problematic aspects of the proposed opt-out collective redress scheme, which may limit its effectiveness and uptake. The first concerns the appointment of the class/settlement representative and the second concerns the potential funding arrangements in relation to opt-out collective proceedings. The article questions whether the combination of these two aspects may dis-incentivise and unnecessarily limit the effectiveness of the new opt-out provisions, although it is accepted that this will also greatly depend on the Competition Appeal Tribunal interpretation and application of its new Tribunal Rules in relation to Collective proceedings, in particular regarding certification, appointment of the class/settlement representative and determination of the appropriate costs and expenses incurred in pursuing a collective claim.
\end{abstract}

\footnotetext{
${ }^{1}$ Professor Barry J Rodger, Law School, University of Strathclyde, barry.j,rodger@strath.ac.uk. An earlier version of this paper was presented at the Roundtable on Private Enforcement and Access to Justice, Tuesday 29 April 2014; Oxford University centre for Competition Law And Policy (Oxford/Stockholm Soderberg Venture and Journal of Antitrust Enforcement). Many thanks to Catriona Munro, John Peysner, Sebastian Peyer and Charles Dhanowa for very helpful comments on an earlier draft though responsibility for all errors and omissions remains mine alone.
} 


\section{Introduction}

This article will provide a critical academic discussion of the key aspects of the dramatically enhanced collective redress mechanisms introduced recently in the UK in relation to competition law infringements by the Consumer Rights Act 2015. There has been extensive academic debate and discussion in recent years in the EU on the development of private enforcement of competition law, ${ }^{2}$ with considerable academic commentary recently in relation to the adoption by the EU of the Antitrust Damages Directive. ${ }^{3}$ However, a particular focus of the debate on increasing competition law private enforcement has been how best to deliver justice and compensation to consumers harmed by competition law infringements, notably price-fixing cartels. The article will first outline the background to the debate on collective consumer redress in the competition law context, primarily driven by access to justice arguments, before a brief comparative outline of the development of collective redress mechanisms in different legal systems. Inevitably, the discussion will start with the US class action mechanism, which has been instrumental in facilitating consumer redress. ${ }^{4}$ The article will then consider recent EU developments, and highlight the introduction of opt-out collective redress mechanisms in a competition law context in other Member States. The article will reflect on the limited provision in the UK on collective redress in relation to competition law infringements prior to the Consumer Rights Act, in particular the limitations in the opt-in follow-on procedure under s47B of the Competition Act 1998, as demonstrated by $C A \vee J J B$. The article will then focus on the Act's provisions (and associated Tribunal rules) in relation to stand-alone/follow-on opt-in/opt-out collective proceedings and settlements (in both follow-on and stand-alone actions). The article will outline the likely effect of the new statutory provisions inserted into the Competition Act 1998, for Collective Proceedings and Collective Settlements respectively. ${ }^{5}$ The Tribunal rules on certification will be considered, noting the potential difficulties in their practical application, before analysis of two further key problematic aspects of the proposed opt-out collective redress scheme, which may limit its effectiveness and uptake. The first concerns

\footnotetext{
${ }^{2}$ See A P Komninos, EC Private Antitrust Enforcement: Decentralised Application of EC Competition Law, (Hart Publishing: 2008); V Milutonivic, Right to Damages' Under EU Competition Law (2010 Kluwer Law International); L A V San Pedro, C A Ledesma, J A E Saenz, C H Suarez and J G Gilsanz (eds) Private Enforcement of Competition Law (Lex Nova, 2011); J Basedow, J P Terichte, L. Tichy (eds), Private Enforcement of Competition Law (Nomos: 2011); see also D McFadden The Private Enforcement of Competition Law in Ireland, (Hart Publishing, 2013) and B Rodger (ed) Competition Law Comparative Private Enforcement and Collective Redress Across the EU (2014 Kluwer Law International).

3 Directive 2014/104/EU (2014) OJ L349/1. See for example, C F Weidt 'The Directive on actions for antitrust damages after passing the European Parliament' [2014] 35(9) ECLR 438-444; A Singh, 'Disclosure of Leniency evidence: examining the Directive on damages actions in the aftermath of recent ECJ rulings' [2014] 7(4) GCLR 200-213.

${ }^{4}$ See for instance A.E. Foer and J.W. Cuneo (eds) The International Handbook on Private Enforcement of Competition Law, (2010, Edward Elgar In association with the American Antitrust Institute); C A Jones, Private Enforcement of Competition Law in the EU, UK and USA, (1999, OUP:Oxford); R H Lande and J P Davis 'Benefits from private Antitrust enforcement: An Analysis of Forty Cases' (2008) 42 University of San Francisco Law Review 879.

${ }^{5}$ Note that the Act also inter alia includes provision on extending the scope of the CAT's role generally in private enforcement:- see for instance A Andreangeli, 'The Changing structure of competition enforcement in the UK: The Competition Appeal Tribunal between present challenges and an uncertain future' (2015) 3(1) JAE 1-30; and in relation for example to CMA facilitated redress:- see for instance C Hodges 'Fast, Effective and Low Cost Redress: How Do Public and Private Enforcement and ADR Compare?' , Ch 8 in Rodger (ed) 2014 supra.
} 
the appointment of the class/settlement representative and the second concerns the potential funding arrangements in relation to opt-out collective proceedings. The article questions whether the combination of these two aspects may dis-incentivise and unnecessarily limit the effectiveness of the new opt-out provisions.

\section{Consumer and Collective Redress Background}

Focusing on consumer redress in the private enforcement context is appropriate for a number of reasons. First, because of the historical and contemporary focus on the 'consumer' at the heart of competition/antitrust law, whether from a neo-classical economic model of perfect competition and monopoly ${ }^{6}$ to the Chicago-School influence on US antitrust and the (limited) concept of the 'consumer welfare', ${ }^{7}$ to a consumer-interest model which has predominated in the European debate on recent years. ${ }^{8}$ Second, because facilitating and incentivising consumer redress chimes with more recent debates in legal practice about 'access to justice', ${ }^{9}$ and facilitating consumer redress generally. Third, because collective redress has been developed by the European Commission as a central theme in the last few years in the EU debate on encouraging and facilitating private enforcement in the EU. ${ }^{10}$ Finally, and related to this third aspect, is the influence of the US antitrust enforcement system in which private enforcement has played a considerably more significant role than in the EU over the last 30 years, and in which 'class actions' have played a pivotal role. On the one hand, the US system demonstrates the potential for consumer redress for competition law infringements, yet at the same time, the EU (and UK) debate on reform has been burdened with a fear of the over-zealous litigant and the 'toxic cocktail' of excessive and costly private enforcement system of which 'class actions' form a central plank. $^{11}$

\footnotetext{
${ }^{6}$ See for instance Scherer and Ross, Industrial Market Structure and Economic Performance (Houghton Mifflin, $3^{\text {rd }}$ edn, 1990); Bishop and Walker, The Economics of EC Competition Law (Sweet \& Maxwell, $3^{\text {rd }}$ edn, 2010), Ch 2.

${ }^{7}$ See R Bork, The Antitrust paradox, $2^{\text {nd }}$ edn, New York: Free Press, 1993. Cf E Fox, 'The battle for the soul of antitrust' (1987) 75 Cal. L. Rev 917 and see also B Foer, AAI Working Paper No. 05-09: The Goals of Antitrust: Thoughts on Consumer Welfare in the U.S. at http://www.antitrustinstitute.org/node/10232; For a more recent discussion, see Kovacic W. E. 'The Intellectual DNA of Modern US Competition Law for Dominant Firm Conduct: The Chicago/Harvard Double Helix' [2007] Columbia Business Law Review 1.

${ }^{8}$ Wyatt and Dashwood, EU law, Oxford: Hart Publishing, 2011, Ch 22 'Introduction to EU Competition Law'; Marsden P and Whelan, P "'Consumer Detriment" and its Application in EC and UK Competition Law' [2007] ECLR 569-585. See the impact on the debate in relation to the Commission review of Article 102 enforcement practice in the Commission Guidelines of 2009 at http://ec.europa.eu/competition/antitrust/art82/index.html.

${ }^{9}$ See, for example the report by the European Union Agency for Fundamental Rights, 'Access to Justice in Europe: An Overview of Challenges and Opportunities', 2011 at http://fra.europa.eu/sites/default/files/fra uploads/1520-report-access-to-justice EN.pdf. In the UK see for instance the Access to Justice Foundation at http://www.accesstojusticefoundation.org.uk/. See also J. Peysner, Access to Justice: A Critical Analysis of Recoverable Conditional Fees and No Win No Fee Funding (Palgrave MacMillan: London, 2014).

${ }^{10}$ See the Commission website at http://ec.europa.eu/competition/antitrust/actionsdamages/index.html as discussed further infra. See A Andreangeli 'Collective redress in EU competition law: an open question with many possible solutions' (2012) World Competition 3 529-558; See C. Hodges 'The European Approach to Justice and Redress' (2011) 53 Supreme Court Law Review (2d) 301-346.

${ }^{11}$ See Albert E Foer and Jonathon W Cuneo The International Handbook on Private Enforcement of Competition Law (AAI, Edward Elgar, 2010), Part II in particular and A Andreangeli 'A view from across the Atlantic: recent developments in the case law of the US Federal courts on class certification in antitrust cases' Chap. 7 in Rodger (ed) 2014 supra and Private Enforcement of Antitrust- Regulating Corporate Behaviour through Collective Claims in the EU and US (2014 Edward Elgar). See also Heffernan L, 'Comparative Common
} 
There has been considerable academic study and literature in relation to collective consumer redress generally, led by the work of Rachel Mulheron, ${ }^{12}$ and empirical work which has highlighted major gaps in redress for consumers specifically in relation to competition law infringements. ${ }^{13}$ The 2013 Commission Recommendation ${ }^{14}$ provided the following definition of collective redress as follows:-

(a) 'collective redress' means (i) a legal mechanism that ensures a possibility to claim cessation of illegal behaviour collectively by two or more natural or legal persons or by an entity entitled to bring a representative action (injunctive collective redress); (ii) a legal mechanism that ensures a possibility to claim compensation collectively by two or more natural or legal persons claiming to have been harmed in a mass harm situation or by an entity entitled to bring a representative action (compensatory collective redress)'. ${ }^{15}$ Accordingly, although there is obviously and intentionally, considerable overlap between the mechanisms for 'collective redress' and the role played by consumers in ensuring access to justice in a competition law context, collective redress and consumer redress do not necessarily fully coincide. ${ }^{16}$

\section{US Class actions}

Essentially, the US legal system has for a considerable period promoted access to the courts for consumers through group lawsuits as this spreads the potential fees and costs burden, and may counteract the inertia of potential individual claimants in diffuse delicts/torts

Law Approaches to Multi Party Litigation; The American Class Action Procedure' (2002) 25 DULJ 102. For criticism of the 'irrational' approach to class actions in Europe, see Schnell, G 'Class Action Madness in Europea call for a more balanced Debate' [2007] ECLR 617-619.

${ }^{12}$ For some of the work undertaken in this field by Rachael Mulheron, see The Class Action in Common Law Legal Systems: A Comparative Perspective (Hart Publishing, Oxford, 2004); 'Recent Milestones in Class Actions Reform in England: A Critique and a Proposal' (2011) 127 Law Quarterly Rev 288-315; 'Opting In, Opting Out, and Closing the Class: Some Dilemmas for England's Class Actions Law-Makers' (2011) 50 Canadian Business L 376-408; 'The Impetus for Class Actions Reform in England Arising From the Competition Law Sector' in S Wrbka et al (eds), Collective Actions: Enhancing Access to Justice and Reconciling Multilayer Interests? (CUP, Cambridge, 2012), ch 15, 385-412; 'A missed Gem of an Opportunity for the Representative Rule' (2011) EBLRev 49-60.

${ }^{13}$ Reform of Collective Redress in England and Wales: A Perspective of Need (Report submitted to the Civil Justice Council of England and Wales, February 2008).

${ }^{14}$ Commission Recommendation of 11 June 2013 on common principles for injunctive and compensatory collective redress mechanisms in the Member States concerning violations of rights granted under Union Law, June 2013, (2013) OJ L201/60, available at http://eurlex.europa.eu/LexUriServ/LexUriServ.do?uri=CELEX:32013H0396:EN:NOT

the Member States concerning violations of rights granted under Union Law

${ }^{15}$ Ibid. para. 3. The ancillary Commission Communication, (COMMUNICATION FROM THE COMMISSION TO THE EUROPEAN PARLIAMENT, THE COUNCIL, THE EUROPEAN ECONOMIC AND SOCIAL COMMITTEE AND THE COMMITTEE OF THE REGIONS, "Towards a European Horizontal Framework for Collective Redress", Strasbourg, 11.6.2013, $\operatorname{COM}(2013)$ final, 401 available at http://ec.europa.eu/consumers/redress cons/docs/com 2013401 en.pdf. ) further noted at para. 3.2 that:'Collective redress is a procedural mechanism that allows, for reasons of procedural economy and/or efficiency of enforcement, many similar legal claims to be bundled into a single court action. Collective redress facilitates access to justice in particular in cases where the individual damage is so low that potential claimants would not think it worth pursuing an individual claim. It also strengthens the negotiating power of potential claimants and contributes to the efficient administration of justice, by avoiding numerous proceedings concerning claims resulting from the same infringement of law.'

${ }^{16}$ See further infra re the collective redress model under the Consumer Rights Act. 
where the small value of potential individual awards may discourage court action. ${ }^{17}$ Collective court mechanisms relying on 'common proof' may also lead to more efficient adjudication by the civil court system. ${ }^{18}$ The key element in the US is the opt-out nature of the class action mechanism, provided for in Rule 23 of the US Federal Rules of Civil Procedure. Although the opt-out basis is crucial in ensuring widespread compensation, ${ }^{19}$ in applying Rule 23 the courts have had to reconcile this underlying aim of efficient adjudication with other potentially conflicting principles such as party autonomy and due process requirements. There are certain key requirements which have to be satisfied under Rule 23 before a court will certify a class action. According to Rule 23 "one or more members of a class may sue or be sued as representative parties on behalf of all members" if the class is sufficiently large to make the joinder of individual claims impracticable and there are questions of fact and/or of law that are common to the class.

Moreover, Rule 23 requires the claims (or defences) of the representative parties to be 'typical' of those of the class and for there to be adequate representation of that class. The former requirement is aimed at avoiding a conflict of interests between the named representative and the class members; ${ }^{20}$ the latter has a similar foundation but the need for a class lawyer to be sufficiently qualified, experienced and competent to conduct class action litigation also stems from the recognition of the force of res judicata of a class action judgment against absent class members. ${ }^{21}$ In ensuring the balance between efficiency and due process, two further conditions were introduced in 1966:- that there existed 1) a predominance of common over individual issues arising from the dispute and that a class action was superior to other methods of fairly and efficiently adjudicating the dispute. Accordingly, although opt-out class actions have been central to the enhanced role for private antitrust enforcement in the USA over the last 40 years at least, the class certification process in that context should not simply be viewed as a rubber-stamping process. Moreover, it is evident that the courts dealing with class certification motions undertake a 'careful scrutiny' ${ }^{22}$ as to whether the requirements in Rule 23 are satisfied, and case-law and academic commentary indicates a significantly more rigorous approach to certification in recent years, ${ }^{23}$ which may reign in any of the perceived excesses of the US opt-out class action mechanism. ${ }^{24}$ In re: Hydrogen peroxide, the Supreme Court stressed

\footnotetext{
${ }^{17}$ See generally Olson The Logic of Collective Action (Cambridge, MA: Harvard University press, 1963). See A Andreangeli, 'Collective redress in EU Competition law: an open question with many possible solutions' (2012) 35(3) W Comp 529; 'A view from across the Atlantic: recent developments in the case law of the US Federal courts on class certification in antitrust cases' Chap. 7 in Rodger (ed) 2014 supra and Private Enforcement of Antitrust-Regulating Corporate Behaviour through Collective Claims in the EU and US (2014 Edward Elgar).

${ }^{18}$ See eg Hawaii v Standard Oil, 405 US 251 at 266.

${ }^{19}$ And thereby in an antitrust context indirectly promoting the concept of competitive markets:-see Elzinga and Breit, The Antitrust Penalties: a study in law and economics, (1976: New Haven, MA, Yale University Press), at pp. 3-4.

20 Newberg and Conte, Newberg on class actions (hereinafter referred to as Newberg), $4^{\text {th }}$ edition, (2011, Thomson Reuters) s 18.8; see e.g. Sunrise Toyota Ltd v Toyota Motors Ltd, 55 FRD 519 at 532-33.

${ }^{21}$ See e.g. Scott, 'Don't forget me! The client in a class action lawsuit', (2001), 15 Geo. J Legal Ethics 561, pp. 569-570 and 573-574; also Newberg, 40.

${ }^{22}$ AmChem Products Inc $v$ Windsor, 83 F. 3d, 610 at 616.

${ }^{23}$ Subject to 'scrupulous scrutiny' per Re Hydrogen peroxide Antitrust litigation 552 F. $3 d 305$ (3 ${ }^{\text {rd }}$ Cir. 2008). The close or scrupulous scrutiny requirement) raises another problem in that it requires an increasing amount of evidence before trial and disclosure.

${ }^{24}$ See e.g. Rajski, 'In Re: hydrogen Peroxide: reinforcing rigorous analysis for class action certification', (2011) 34 Seattle UL Rev 577 at 603-604; Bone and Evans, 'Class certification and the substantive merits', 51(4) Duke L
} 
that each requirement of Rule 23 must be met and that class certification requires a thorough examination of the factual and legal allegations. Accordingly, a district court errs as a matter of law when it fails to resolve a genuine legal or factual dispute relevant to determining the certification requirements. In that case, the Supreme Court reviewed the way the District Court had dealt with the issue of predominance and vacated the class certification order.

The key point is that the US courts have sought to reconcile and balance the conflicting principles underlying the class action mechanism, but the more scrupulous approach in this context may indeed discourage class action claims and thereby weaken the class action as an enforcement tool and method of ensuring collective consumer redress. This is particularly significant given recent debates generally in the EU, and more specifically in the UK in relation to the Consumer Rights Act, regarding the impact of introducing an opt-out collective mechanism. The EU ultimately decided not to propose the opt-out class action model, ${ }^{25}$ and the fear of over-incentivising lawyers has clearly influenced the Parliamentary debate in the UK during the passage of the Consumer Rights Bill.

As noted above, the second and related facet that drives US private enforcement generally, and class actions in particular, is the funding of actions, reliant on the availability of contingency fees. ${ }^{26}$ No win-no fee contingency fees appeal to potential claimants because of the absence of the risk of having to pay considerable legal fees should a claim be unsuccessful. They also incentivise lawyers because, in the event of success, the lawyers take a percentage of the overall damages award or agreed settlement sum; this is generally circa. $30 \%$ of the antitrust damages awarded. This can lead to very profitable work for lawyers where antitrust settlements can be upwards of $\$ 1$ bn in some cases, partly as a result of the threat of treble damages. Nonetheless, although lawyer 'greed' and profitability has been a central concern during the passage of the relevant provisions of the Consumer Rights Act through Parliament, the empirical study by Lande and Davis of antitrust contingency fees in US antitrust settlement, demonstrated the supervisory jurisdiction of the courts ${ }^{27}$ and the general acceptance by those courts of the appropriateness of fee levels in settled antitrust disputes. ${ }^{28}$

The misconceptions about the US class action mechanism:- the perceived lack of supervision of class counsel in the US class system and the fee incentives to lawyers; has meant that the debate in Europe generally, and the UK specifically has been driven by a generalised (and unsubstantiated) fear about the creation of a system driven by ambulancechasing lawyers maximising self-interest at the expense of the class, ${ }^{29}$ 'blackmailing' defendants into settling for vast sums. ${ }^{30}$

J 1251 at 1328-1330; Jacobson and Choi, 'Curtailing the impact of class certification on antitrust policy', (2011) 66 NYUANSAL 549 at 554-555.

${ }^{25}$ See further infra.

${ }^{26}$ See C Wildfang and S P Slaughter 'Funding Litigation', Chapter 12 in Albert E Foer and Jonathon W Cuneo The International Handbook on Private Enforcement of Competition Law (AAl, Edward Elgar, 2010).

${ }^{27}$ As provided for in Rule 23 FRCP.

${ }^{28}$ See Lande and Davis, 'Benefits from private Antitrust enforcement: An Analysis of Forty Cases' (2008) 42 University of San Francisco Law Review 879, although their sample selection is skewed towards bigger cases with (greater) benefits.

${ }^{29}$ See inter alia Helveston, 'Promoting justice through public interest advocacy in class actions', (2012) 60 BF L Rev 749 at 777-778; also Tidmarsh, 'Rethinking adequacy of representation', (2009) 97 Tx. L Rev 1137 at 11561158.

${ }^{30} \mathrm{Cf}$ the tone and conclusions of the Taylor Report and also the current Scottish Government Consultation on Expenses and Funding of Civil Litigation in Scotland, discussed further below. 


\section{EU debate on Collective Redress}

The EU competition law enforcement landscape has been changing, albeit slowly, since the EU Commission began to encourage private enforcement since the early 1990s; partly to enhance the deterrence and effectiveness of EU competition law and alleviate its own resource limitations. The Ashurst Report and subsequent Green and White Papers on 'Damages actions for breach of the EC Antitrust Rules', 31 had demonstrated the Commission's intention to consider mechanisms to facilitate private competition law enforcement across the EU, to allow for a new wave of litigation following the 2002 Leniency notice and the so-called European cartel enforcement revolution. ${ }^{32}$ There was discussion in DG Comp about the possibility of introducing a sector specific collective redress mechanism, but the Commission decided to proceed on a horizontal basis with a public consultation entitled 'Towards a coherent European approach to collective redress', ${ }^{33}$ aimed at identifying common legal principles on collective redress and to examine how they could be adapted to fit the EU Member States' legal systems and into the legal orders of the then 27 EU Member States, prior to the accession of Croatia. The European Parliament made an important contribution to this process particularly by adoption of its resolution of 2 February 2012, also entitled- "Towards a Coherent European Approach to Collective Redress". ${ }^{34}$ In this period there was also a Collective Redress Study produced for DG for Internal Policies, ${ }^{35}$ which proposed the following as the key legal objectives of an antitrust collective redress mechanism-

'i) to discourage unmeritorious actions, while guaranteeing that those who have actually suffered harm obtain and adequate and fair compensation;

(ii) to ensure a fair trial by providing legal certainty and consistency;

(iii) to lower the financial and organisational hurdles that consumers and small businesses face. ${ }^{36}$ It proceeded to consider that an opt-out mechanism should be exceptionally permitted, partly due to the low participation in opt-in models.

Subsequently the European Commission published its Communication and Recommendation on Collective Redress in June 2013. The key choice in determining an appropriate collective redress model, is whether to allow opt-in or opt-out forms of action. Under an opt-in model the claimants must take action to be included in the class, whereas in the opt-out system claimants, who have the same interest, are automatically included in the class by default unless they express exclusion from the class. Accordingly this model can reduce the defendant and court's costs. The opt-in system is limited in that "[r]equiring the individuals affirmatively to request inclusion in the lawsuit would result in freezing out the claims of people - especially small claims held by small people - who for one reason or

\footnotetext{
${ }^{31}$ Ashurst 'Study on the conditions of claims for Damages in case of Infringement of EC Competition Rules,' $31^{\text {st }}$ August 2004, available at http://ec.europa.eu/competition/antitrust/actionsdamages/index.html.

32 For a detailed discussion of this issue, see A Riley, 'Beyond Leniency: Enhancing Enforcement in EC Antitrust Law' (2005) 28(3) World Competition 377-400.

${ }^{33}$ See generally http://ec.europa.eu/consumers/redress cons/collective redress en.htm\#comrec.

${ }^{34}$ http://www.europarl.europa.eu/sides/getDoc.do?pubRef=-//EP//TEXT+TA+P7-TA-2012$0021+0+D O C+X M L+V 0 / / E N$.

${ }^{35}$ See DG for Internal Policies, Policy Department, Economic and Scientific Policy, Collective Redress in Antitrust Study 2012, available at http://www.europarl.europa.eu/document/activities/cont/201206/20120613ATT46782/20120613ATT46782E N.pdf.

$\overline{{ }^{36} \text { Ibid at }}$ p12.
} 
another, ignorance, timidity, unfamiliarity with business or legal matters, will simply not take the affirmative step. [..] In [such] circumstances [..] it seems fair for the silent to be considered as part of the class". ${ }^{37}$ There is also a risk that after the initial class action a defendant may still face a large group of consumers that may attempt to use the precedent value of the initial successful opt-in class action as a "free ride" to bring waves of successive individual claims. ${ }^{38}$

The 2013 Commission Communication noted that business stakeholders opposed the 'optout' model and consumer organisations viewed it as desirable in delivering effective justice. ${ }^{39}$ It, however, considered that the opt-out model curtailed claimant freedom in making informed decisions, and, rather bizarrely, that it may be inconsistent with the central aim of collective redress on the basis that parties are not identified and accordingly an award cannot be distributed to them. ${ }^{40}$

The Commission recommended that Member States should have collective redress mechanisms in place to ensure effective access to justice, but the general rule is that these should be based on the opt-in model, with exceptional resort to an opt-out model justified on the basis of the sound administration of justice. ${ }^{41}$ Furthermore, the Recommendation provides that Member States should not permit contingency fees and punitive damages are to be prohibited. ${ }^{42}$ However, the continued rejection of the "opt-out" model in the EU seems increasingly difficult to justify in light of the US federal courts' "careful scrutiny" approach to certification. ${ }^{43}$ Nonetheless, as will become clear, the reform of collective redress in the UK has not been fully constrained by the EU Commission scepticism regarding opt-out mechanisms.

\section{EU Member States and Collective Redress}

Despite the Commission's reluctance to consider an opt-out model, it was noted, following the Commission's White Paper publication, that "The opt-out mechanism is present - albeit in various forms - in four major European countries. It is as much part of this European experience as any other model." ${ }^{\prime 44}$ Delatre indicated that class action mechanism can act as a choice architecture, a 'nudge ${ }^{\prime 45}$ in which the model of passive consent overcomes the traditional mode of rational apathy, exemplified by the incredibly low rates of participation

\footnotetext{
37 B. Kaplan, 'Continuing Work of the Civil Committee: 1966 Amendments of the Federal Rules of Civil Procedure' (I), 81 Harvard Law Review, 356, at 397-8

${ }^{38}$ W.Eyskens and N.Kaluma, 'Opt-out is Hardly an Option Chapter - Class and Group Actions 2012', Chapter 4 in The International Comparative Legal Guide to Class and Group Actions, 2012 (Global Legal Group in Association with CDR).

${ }^{39}$ Supra para 3.4.

${ }^{40}$ Ibid.

${ }^{41}$ Commission Recommendation supra n14 at para 21.

42 Ibid at paras 30-31.

${ }^{43}$ See A Andreangeli 'A view from across the Atlantic: recent developments in the case law of the US Federal courts on class certification in antitrust cases' Chap. 7 in Rodger (ed) 2014 supra and Private Enforcement of Antitrust-Regulating Corporate Behaviour through Collective Claims in the EU and US (2014 Edward Elgar).

${ }^{44}$ See J. G. Delatre, 'Beyond the White Paper: rethinking the Commission's Proposal on private antitrust litigation' (2011) 8(1) Comp. L. Rev. pp29-58. See also Gaudet, R,'Turning a Blind Eye: the Commission's Rejection of Opt-out Class Actions Overlooks Swedish, Norwegian, Danish and Dutch Experience' [2009] ECLR 30(3), 107-117. Heffernan L, 'Comparative Common Law Approaches to Multi Party Litigation; The American Class Action Procedure' (2002) 25 DULJ 102.

${ }^{45}$ R H Thaler and C R Sunstein, Nudge: Improving Decisions about Health, Wealth and Happiness (Caravan, Yale University Press, Yale 2008).
} 
in opt-in actions. Given that an individual consumer is likely to be seeking a very minimal sum, it may be difficult to encourage that person to seek redress due to the potential costs involved in litigation- and this is one of the reasons that collective redress acts as an incentive. Across the Member States we can observe a spectrum of potential mechanisms which may provide for collective redress for consumers. ${ }^{46}$ Clearly, most of the collective redress mechanisms across the EU to date have been opt-in models, but these have been criticised for their limited impact and effectiveness with very low take up rates. Accordingly a major part of the debate in the EU, and borrowing heavily from the US class action tradition, ${ }^{47}$ has been whether an opt-out mechanism should be adopted, and there are already examples of an opt-out representative model in various Member states already. Furthermore, in various Member State there have been recent and ongoing reform discussions in this context, and various types of 'collective action' mechanism introduced across certain Member States in the last few years. Accordingly, while the recent nonbinding Recommendation by the Commission is important in seeking to build a consensus, ${ }^{48}$ and a minimum level playing field across Europe in a way that supports, encourages and activates consumer redress (whilst always fearful of the term 'class action') it is notably cautious and conservative given recent reforms and on-going discussions in certain Member States at least. The point is that this is not a process in which the UK is isolated, albeit, the reforms should place the UK at the forefront of competition law consumer redress in the EU. However it is important to stress the marginal role played by consumers to date in the enforcement of competition law through the courts in the EU. In research led by the author across EU member States between 1 May 1999 and 1 May 2012, of all the competition law case-law, only 3.6\% were 'consumer' cases, with $3.2 \%$ individual consumer cases and $0.4 \%$ involving aggregated/'class' consumer cases with the vast majority at $96.4 \%$ comprising nonconsumer cases. ${ }^{49}$

The EU Member States have a varied and variable landscape of provision for collective actions. However, appreciation of the different provision may encourage tentative sharing of practice about the best way forward, though not necessarily support the approach of the Commission, which is, perhaps inevitably, to endorse harmonisation at the lowest common level. ${ }^{50}$ Indeed the outcome to the Commission's consultation was probably unsurprising given the rhetoric in relation to the toxic cocktail of mechanisms supporting the US antitrust class action system. ${ }^{51}$

\footnotetext{
${ }^{46}$ See B Rodger, 'Collective Redress Mechanisms and Consumer Case-Law' Chapter 5 in B Rodger (ed) Competition Law Comparative Private Enforcement and Collective Redress Across the EU (2014 Kluwer Law International).

47 See Albert E Foer and Jonathon W Cuneo, The International Handbook on Private Enforcement of Competition Law (AAl, Edward Elgar, 2010), Part II.

${ }^{48}$ See discussion by D-P. L. Tzakas, 'Collective Redress in the Field of Competition Law: the need for an EU remedy and the impact of the recent Commission Recommendation' (2014) 41(3) Legal I.E.I. 225-242.

${ }^{49}$ See supra $\mathrm{n} 48$.

${ }^{50}$ See for instance, R Amaro 'Collective Redress, consensual settlements, and other Incentive Devices: Plurality is the Key' Research Paper, Brussels, 7 November 2011, GCLC $9^{\text {th }}$ annual conference- 'Antitrust Damages in EU law and Policy'.

${ }^{51}$ Amongst many statements to this effect by EU leaders, see Communication from the Commission "Towards a European Horizontal Framework for collective Redress", COM(2013) 401/2, para 2.2 (“'Class actions' in the US legal system are the best known example of a form of collective redress but also an illustration of the vulnerability of a system to abusive litigation."); European Commission DG SANCO, MEMO/08/741, 2009, p 4 ("The U.S. style class action is not envisaged. EU legal systems are very different from the U.S. legal system which is the result of a 'toxic cocktail'-a combination of several elements (punitive damages, contingency
} 


\section{The UK and Collective Redress}

Prior to the Consumer Rights Act, there was limited scope for collective redress in the UK courts, generally, and specifically in relation to competition law. In England and Wales, there exists the possibility of bringing a test case; consolidation and single trial of multiple actions; a GLO (Group Litigation order) and a representative action. ${ }^{52}$ Nonetheless the Civil Justice Council issued a Report outlining the limitations of each of these options and recommending the introduction of a new collective procedure, allowing particular cases to proceed on an opt-in or opt-out basis. ${ }^{53}$ In particular, the difficulties in bringing collective actions under existing mechanisms, at least in relation to aggregated claims by businesses, was demonstrated by Emerald Supplies Ltd v British Airways Plc. ${ }^{54}$ In that case the Court of Appeal dismissed an appeal against the High Court's earlier judgment striking-out the "representative" element of a claim for damages brought by Emerald Supplies Ltd and Southern Glasshouse Produce, two importers of fresh produce, against British Airways Plc (BA) arising from BA's breach of competition law. This was not a consumer collective claim but it demonstrated the limitations of the Civil Procedure Rules (CPR) r.19.6 on the basis that the purported claimant class did not all have the 'same interest' in the claim. ${ }^{55}$

In terms of Scottish court procedure for multi-party actions, there has been a serious debate regarding the introduction of a collective litigation mechanism for over thirty years. ${ }^{56}$ To date, no concrete reforms have been enacted. More recently, the Lord Gill (Scottish Civil Courts) Review (or SCCR) again recommended the introduction of a multi-party procedure. ${ }^{57}$ The SCCR endorsed a flexible form of action where the court will decide on a case-by-case basis whether a class action should be opt-in or opt-out. ${ }^{58}$ The SCCR explicitly referred to the facts of the $J J B$ case as the appropriate kind of situation for a court to allow an opt-out action to proceed. ${ }^{59}$ Much of the SCCR Review agenda is expected to be realised following

\footnotetext{
fees, opt-out, pre-trial discovery procedures).... This combination of elements - "toxic cocktail" - should not be introduced in Europe. Different effective safeguards including, loser pays principles, the judge's discretion to exclude unmeritorious claims, and accredited associations which are authorised to take cases on behalf of consumers, are built into existing national collective redress schemes in Europe."). See G Schnell, 'Class Action Madness in Europe- a Call for a More Balanced Debate' [2007] ECLR 617-619.

${ }^{52}$ See 'Improving Access to Justice Through Collective Actions' Developing a More Efficient and Effective Procedure for Collective Actions, Final Report, Nov 2008, Civil Justice Council, http://www.judiciary.gov.uk/JCO\%2FDocuments\%2FCJC\%2FPublications\%2FCJC+papers\%2FCJC+Improving+AC cess+to+Justice+through+Collective+Actions.pdf.

53 Ibid.

${ }^{54}$ See for instance in the UK Emerald Supplies Ltd v British Airways PIc [2009] EWHC 741 (Ch). The problem was arguably that the claim was also brought on behalf of direct and indirect purchasers. A damages award to the direct purchasers logically reduces the damages award to the indirect purchasers, i.e. they do not have the same interest.

${ }^{55}$ (2011) G.C.L.R. 4(1) R13-14.

${ }^{56}$ Class Actions and the Scottish Case: A new way forward for consumers to obtain redress? (Scottish Consumer Council; 1982: Edinburgh); Multi-Party Actions: Report on a reference under s3(1)(e) of the Law Commissions Act 1965 (Scottish Law Commission; 1996: Edinburgh); C Ervine A Class of their Own: Why Scotland needs a class action procedure (Scottish Consumer Council; 2003: Edinburgh); a petition demanding the introduction of a class action procedure was also presented to the Scottish Parliament's Public Petitions Committee in March 2009.

57 Report of the Scottish civil Courts Review 2009 Vol. 2 Chap. 13 Multi-Party Actions, available at https://www.scotcourts.gov.uk/about-the-scottish-court-service/the-scottish-civil-courts-reform.

${ }^{58}$ Ibid at para. 75.

${ }^{59}$ Ibid at para. 79.
} 
the establishment of the Scottish Civil Justice Council. ${ }^{60}$ Indeed the Scottish Government is currently consulting on its Expenses and Funding of Civil Litigation Bill. Following the Taylor Report, $^{61}$ the consultation sets out legislative proposals to facilitate funding of civil litigation, ${ }^{62}$ and also sets out proposals for a multi-party action as recommended by the SCCR. ${ }^{63}$ The consultation sets out three alternative options:- Option 1 would be a case management procedure for mass litigation on an opt-in basis; ${ }^{64}$ Option 2 would be to introduce a full class action procedure on an opt-in or opt-out basis; ${ }^{65}$ and the third more ambitious option (option 3) would extend Option 2 to also allow third parties to bring representative actions on an opt-out basis. ${ }^{66}$ The consultation document noted that Option 2 had the potential to provide an effective model for mass litigation generally, though may have to be balanced against the desire to create an 'overly litigious culture' ${ }^{67}$ and that Option 3 would facilitate collective redress. As will be discussed later in relation to the new competition law Collective Proceedings mechanisms, the Consultation recognises the importance of appropriate funding mechanisms generally for civil litigation and, following the Taylor Report, recommends inter alia the enforceability of DBA's by solicitors in Scotland. ${ }^{68}$ Albeit in the context of personal injury actions, Taylor's Report highlighted a 'David and Goliath relationship' between claimants and defendants and that his recommendations on litigation funding set out to recalibrate this 'asymmetric relationship'. ${ }^{69}$ This description can be applied even more cogently in the context of collective consumer redress for competition law infringements.

In the specific competition law context, section 19 of the Enterprise Act 2002 had earlier added section 47B to the Competition Act 1998, allowing follow-on damages claims to be brought before the CAT by a specified body on behalf of two or more consumers who have claims in respect of the same infringement, ${ }^{70}-a$ form of 'consumer representative action'. ${ }^{71}$ The representative body required the consent of the individuals to pursue their claims, ie it was an opt-in representative action. ${ }^{72}$ Section 47B was inserted to support an underlying aim of the Enterprise Act to reinforce the links between competition law and consumers. However, the only specified body was Which? (the Consumers' Association), ${ }^{73}$ and there has only been one, albeit high-profile, section 47B claim:- Consumers' Association $v$ JJB Sports plc ${ }^{74}$ in relation to Football Shirts. ${ }^{75}$ The claim was for compensatory damages and also

\footnotetext{
${ }^{60}$ The Scottish Civil Justice Council was established on May 282013 under the Scottish Civil Justice Council and Criminal Legal Assistance Act 2013.

${ }^{61}$ See http://www.gov.scot/About/Review/taylor-review.

${ }^{62}$ Consultation available at http://www.gov.scot/Publications/2015/01/9932.

${ }^{63}$ Scottish Civil Courts Review Chapter 13 (Vol.2).

${ }^{64}$ Consultation supra n63 paras 142-149.

65 Ibid paras. 150-162.

${ }^{66}$ Ibid. paras 163-169.

${ }^{67}$ Ibid para 161, particularly if DBA's were available.

${ }^{68}$ Ibid paras 54-55.

69 Ibid. para 24.

${ }^{70}$ Section $47 \mathrm{~B}(1)$ and (4). Subsections 9-10 make provision regarding the specification of a body by the Secretary of State.

${ }^{71}$ See for instance, The Consumers' Association v JJB Sports plc (CAT Case 1078/7/9/07), a follow-on consumer representative action under these provisions before the CAT in relation to Replica Kits.

${ }^{72}$ Section 47B(3).

${ }^{73}$ Pursuant to Specified Body (Consumer Claims) Order 2005, SI 2005/2365.

${ }^{74}$ Case no $1078 / 7 / 9 / 07$.
} 
contained an interesting claim for exemplary or restitutionary damages of $25 \%$ of the relevant turnover of the defendant. Ultimately, this action, following a day of mediation, with only 144 consumers becoming party to the action, was settled on the basis of compensation up to a maximum of $£ 20$ per individual consumer, ${ }^{76}$ and the action was withdrawn. At least in this case it was relatively straightforward for claimants to prove purchase by production of the relevant football shirts, which changed regularly. This case was positive in demonstrating that some consumers could obtain reimbursement of their 'overcharge' but also negative as the numbers were so limited. It should be noted that the defendant, JJB Sports, offered a gesture of goodwill, by offering a free England away shirt and a mug in return for production of a shirt of the relevant period and upon agreement not to pursue JJB further. Apparently around 12,000 consumers took up this offer, and the follow-on action therefore had a positive indirect effect. Another downside in relation to this dispute was the difficulties encountered by the Consumers' Association in recovering their costs. ${ }^{77}$

The clear limitations of the specialist representative action introduced in 2002 under section 47B of the 1998 Act, notably the low participation rates in opt-in schemes due to a lack of incentives, ${ }^{78}$ were acknowledged by the OFT which in 2007 recommended the introduction of an opt-out procedure specifically for competition law. Subsequently, in 2012 the Department for Business, Innovation and Skills in the UK ('BIS') consulted on proposals to reinforce the system of private enforcement in the UK through important reforms. ${ }^{79}$ There has been considerable academic commentary and critique of the effectiveness of those earlier provisions, ${ }^{80}$ and there are important litigation strategy reasons why follow-on claims are not raised before the specialist court, the Competition Appeal Tribunal. ${ }^{81}$ The revised provisions of the Competition Act 1998 will enhance the role of the specialist court, the CAT by extending its competence to hear stand-alone actions as well as follow-on actions, and allow parties to seek injunctions as well as monetary awards. ${ }^{82}$ The key proposal by BIS, at

\footnotetext{
${ }^{75}$ As Replica Football Kit had become known in the CAT follow-on case. See discussion of the case and its background by Rodger, chapter 13, in B Rodger (ed) Landmark Cases in Competition Law: Around The World in Fourteen Stories (Kluwer Law International, 2012).

76 If receipts had been retained, see http://www.which.co.uk/news/2008/01/jjb-to-pay-fans-over-footballshirt-rip-off-128985.jsp.

${ }^{77}$ Note the subsequent judgment by the CAT in January 2009 re interim payment and costs, [2009] CAT 3.

${ }^{78}$ See M Hviid and J Peysner 'Comparing Economic Incentives Across EU Member States' Chapter 6 in Rodger (ed) 2014 supra.

${ }^{79}$ See BIS 12/742, 'Private Actions in Competition Law: A Consultation on Options For Reform', April 2012, and BIS 14/556, 'Consumer Rights Bill: Statement on Policy Reform and Responses to Pre-Legislative Scrutiny', January 2014.

${ }^{80}$ See Robertson, A 'Litigating under the Competition Act 1998: The early Case-law' [2002] Comp. L. J. 4(1) pp335-344 and 'Litigating under the Competition Act 1998: recent Case-law: Part 2' [2004] Comp. L. J. 3(2) pp85-100. Rodger, B. 'Competition Law Litigation in the UK Courts: a study of all cases 2005-2008'- Parts I and II [2009] 2 Global Competition Litigation Review 93-114 and 136-147 and 'Competition Law litigation in the UK Courts: A study of all cases 2009-2012' [2013] 6(2) GCLR 55-67; M Furse, 'Follow-on Actions in the UK: Litigating Section 47A of the Competition Act 1998' (2013) 9(1) Euro C.J. 79-103.

${ }^{81} \mathrm{Ibid}$ and see in particular P Akman, 'Period of limitations in follow-on competition cases: when does a "decision" become final' (2014) 2(2) JAE 389-421.

82 These key changes to the role and competence of the CAT have been addressed by A Andreangeli, 'The Changing structure of competition enforcement in the UK: The Competition Appeal Tribunal between present challenges and an uncertain future' (2015) 3(1) JAE 1-30. Note that the power to award injunctions only relates to proceedings before the Tribunal in England and Wales and Northern Ireland, and an interdict is not available in relation to Scottish proceedings.
} 
least in the context of collective redress, was to recommend the adoption of an opt-out representative collective action for consumers and businesses (in follow-on and stand-alone claims), ${ }^{83}$ together with mechanisms for CAT approved collective settlements. Furthermore, there were proposals to introduce an innovative scheme to enable the competition authorities to certify a voluntary redress scheme. ${ }^{84}$ Each of these BIS recommendations was included in reforms to be made to the existing Competition Act regime, originally by clause 82 and Schedule 7 of the Consumer Rights Bill, when the Bill was first introduced to Parliament on $23^{\text {rd }}$ January 2014. The Act was given Royal Assent on 26 March 2015 and the changes to the Competition Act 1998 regime, introduced section 81 and Schedule 8 to the 2015 Act, come into effect on a date appointed by statutory instrument. As indicated above, the Act contains provision to enable the CMA to certify a voluntary redress scheme, and one prominent academic commentator believes that this innovation may be more important in practice than reliance simply on a private enforcement model. ${ }^{85}$ However, it is suggested here that potentially the most significant reform is the introduction of an opt-out representative collective redress mechanism, and it is this aspect of the reforms that we will be focusing on in the remainder of the article, together with the related set of provisions for collective settlements. ${ }^{86}$

\section{The Key Features of the UK Collective Redress Model}

The competition law provisions of the Consumer Rights Act comprise s81 and Schedule 8, and effectively make changes to the Competition Act 1998 regime for private enforcement, as introduced by the Enterprise Act 2002. The new, revised section 47B of the Competition Act 1998 provides for both opt-out and opt-in collective proceedings before the CAT, and is no longer limited to opt-in proceedings. The introduction of a collective settlement mechanism, ${ }^{87}$ based on the Dutch model, ${ }^{88}$ should facilitate the collective settlement of claims, and there are identical parallel provisions on the authorisation of the settlement representative where a Collective Proceedings Order ('CPO') has not already been made. ${ }^{89}$ The remaining sections of this article will focus on certification of the collective proceedings and the incentives to institute opt-out actions. However, the UK Parliamentary debates concerning these central aspects of an effective opt out procedure were clearly impacted by concerns about the consequences of potentially introducing an American style litigation process and culture. This tension was exemplified by the introductory remarks by the Secretary of State for Business, Vince Cable, at $2^{\text {nd }}$ Reading of the Bill in the House of Commons on 28 January 2014. He noted the limitations in existing provision as follows:- 'In 10 years, there has only been one collective action case in this country, and only one $10^{\text {th }}$ of

\footnotetext{
${ }^{83}$ See 'Private Actions in Competition Law: A consultation on options for reform- government response' Jan 2013 available at https://www.gov.uk/government/uploads/system/uploads/attachment data/file/70185/13501-private-actions-in-competition-law-a-consultation-on-options-for-reform-government-response1.pdf at paras 5.11-5.23.

84 Ibid at paras. 6.20-6.26.

85 See C Hodges 'Fast, Effective and Low Cost Redress: How Do Public and Private Enforcement and ADR Compare? , Ch 8 in Rodger (ed) 2014 supra.

${ }^{86}$ For early discussion of the proposed reforms- see S Wisking, $\mathrm{K}$ Dietzel, $\mathrm{M}$ Herron 'The Rise and Rise of Private Enforcement in the United Kingdom- Government Announces far-Reaching Overhaul of the Competition Law Private Actions Regime' [2013] 6 GCLR 78-77.

${ }^{87}$ Sections $49 \mathrm{~A}$ and $49 \mathrm{~B}$ in relation to where a CPO has been made/has not been made respectively.

${ }^{88}$ Introduced under the Collective Settlement of Mass Claims Act 2005.

${ }^{89}$ Under $\mathrm{s} 49(\mathrm{~B})$.
} 
$1 \%$ of the consumers who were eligible signed up for it. ${ }^{90}$ Nonetheless he stressed:- 'We have tried to strike a careful balance. We do not want an American-style system of prodigious and constant litigation, which would be costly and benefit only lawyers.... ${ }^{91}$ Another opposition spokesperson similarly queried how the legislation could 'bring benefit to competition law from the increased and enhanced perspective of such private actions, to ensure that competition acts in the interests of the consumer?' while seeking to 'prevent the American-style litigation culture. ${ }^{92}$ There was sporadic Parliamentary criticism of the 'scaremongering' ${ }^{93}$ regarding concerns over the allegedly highly litigious US society being replicated in the UK. ${ }^{94}$. Nonetheless, despite the manifold requirements under the US CP Rule 23 regarding certification of a class action and the judicial scrutiny regarding their satisfaction, the misconceived fear of an 'American-type' action required Government spokespersons to stress during the passage of the Bill the 'safeguards' built into the UK collective action model. ${ }^{95}$ These safeguards are effectively:- a requirement for the CAT to certify that a representative is suitable to bring proceedings. ${ }^{96}$; and a ban on exemplary damages awards and the prohibition on damages-based agreements. ${ }^{97}$ At all stages the Government rebuffed attempts to incorporate more specific certification rules within the legislation, on the basis that those would be included in Tribunal rules, which would be adopted after a full consultation process, ${ }^{98}$ and the CAT was deemed to be best placed to exercise the discretion which would be inherent in achieving the underlying aims of the legislation in applying those Rules. ${ }^{99}$

\section{The Consumer Rights Act 2015 and Competition Law- Key Schedule 8 Provisions}

The key provision is the introduction of an amended s47B of the Competition Act. Section $47 \mathrm{~B}(1)$ allows two or more claims to which s47A applies, ${ }^{100}$ to be combined as collective proceedings, ${ }^{101}$ where they are commenced by a representative. ${ }^{102}$ The legislation provides

\footnotetext{
${ }^{90}$ Hansard, HC, 28 January 2014, Col 775.

91 Ibid., col. 776 .

92 Stella Creasey, Hansard, HC, Committee Debate, $11^{\text {th }}$ March 2014, col.579

${ }^{93}$ Baroness King of Bow, Grand Committee, House of Lords, $3^{\text {rd }}$ November 2014, Col. 570.

${ }^{94}$ See for example Baroness Noakes, ibid at Col. 574. See also at col. 575 where she referred to a 'US-style litigation environment' in which she considered that opt-out collective proceedings could 'end up distracting businesses' and the evidence from the US was that they 'do not satisfy consumers' though she did not indicate any source for this purported evidence.

95 See for instance Baroness Hayter of Kentish town, Grand Committee, House of Lords, $3^{\text {rd }}$ November 2014, Col. 579. See C Hodges and R Money-Kyrle 'Safeguards in Collective Actions' (2012) 19(4) Maastricht Journal of International and Comparative Law 477-504.

${ }^{96}$ Baroness Neville-Rolfe, Grand Committee, House of Lords, $3^{\text {rd }}$ November 2014, Cols. 570-581.

${ }^{97}$ More accurately, a provision that declares them to be unenforceable.

${ }^{98}$ See http://www.catribunal.org.uk/247-8763/Draft-Tribunal-Rules.html, discussed further infra.

${ }^{99}$ Baroness Neville-Rolfe, Grand Committee, House of Lords, $3^{\text {rd }}$ November 2014, Col. 582. See also Baroness Neville-Rolfe, Grand Committee, House of Lords, Report, $2^{\text {nd }}$ sitting, $24^{\text {th }}$ November 2014 cols. 743-746.

${ }^{100}$ M Furse, 'Follow-on Actions in the UK: Litigating Section 47A of the Competition Act 1998' (2013) 9(1) Euro C.J. 79-103.

${ }^{101}$ S47B(3)-(b)the proceedings may combine claims which have been made in proceedings under section 47A and claims which have not, and (c) a claim which has been made in proceedings under section 4547A may be continued in collective proceedings only with the consent of the person who made that claim. ${ }^{102}$ S47B(2).
} 
for the CAT to make a Collective Proceedings $\operatorname{Order}^{103}$ in relation to a claim only on the basis that there is:- an authorised representative; ${ }^{104}$ and the claims raise the same, similar or related issues of fact or law and are suitable for collective proceedings. ${ }^{105}$ This is a very broad definition of what can constitute a class where all class members have the same interest. A Collective Proceedings Order must include:- ${ }^{106}$ (a)authorisation of the person who brought the proceedings to act as the representative in those proceedings, (b)description of a class of persons whose claims are eligible for inclusion in the proceedings, and (c)specification of the proceedings as opt-in collective proceedings ${ }^{107}$ or opt-out collective proceedings. ${ }^{108}$ Accordingly, a key aspect of the CAT's role will be to determine whether to specify the proceedings as opt-out collective proceedings. It should be noted that in such proceedings, any non-UK domiciled class member ${ }^{109}$ must opt-in by notifying the class representative. ${ }^{110}$ Section $47 \mathrm{~B}(8)$ provides for authorisation of the class representative in collective proceedings whether or not that representative is a 'class member' ${ }^{111}$ Another crucial provision is $\mathrm{s} 47 \mathrm{~B}(8)(\mathrm{b})$ which specifies that authorisation will only be granted:- if the Tribunal considers that it is just and reasonable for that person to act as a representative in those proceedings.' Collective settlements may be approved under s49A where a Collective Proceedings Order has been made and the CAT is satisfied that the settlement is just and reasonable, and there are parallel provisions in $\mathrm{S} 49 \mathrm{~B}$ of the amended Competition Act 1998 - in relation to eligibility for Collective Proceedings and appointment as a representative- for Collective Settlements where a Collective Proceedings Order has not been made. The legislative provision is sparse on the central issues regarding opt-out collective proceedings:- eligibility as a collective proceeding; whether it should be on an optin or opt-out basis; and the appointment of a suitable class representative. Each of these issues is dealt with in fuller detail in the Tribunal Rules which were finalised for this purpose, ${ }^{112}$ following a period of consultation. ${ }^{113}$

\section{Certification of Collective Proceedings}

Throughout parliamentary debate on the Bill, the Government sought to avoid attempts to straight-jacket the Tribunal by legislative provision, and accordingly one must look beyond

\footnotetext{
${ }^{103}$ As required under $\mathrm{s} 47 \mathrm{~B}(4)$ of the 1998 Act.

${ }^{104}$ In s 47B(5)(a) of the Competition Act 1998.

105 In s 47B(6) of the Competition Act 1998.

${ }^{106}$ S47B(7).

107 S 47B(10) provides that "OOpt-in collective proceedings" are collective proceedings which are brought on behalf of each class member who opts in by notifying the representative, in a manner and by a time specified, that the claim should be included in the collective proceedings.'

108 S47B(11) states that:- "'Opt-out collective proceedings” are collective proceedings which are brought on behalf of each class member except-

$\begin{array}{llll}\text { (a)any class } & \text { member outs by } \\ \text { representative, in a manner and by a time specified, that the }\end{array}$ claim should not be included in the collective proceedings...'

109 Section 59(1B) provides that 'Sections 41, 42, 45 and 46 of the Civil Jurisdiction and Judgments Act 1982 apply for the purpose of determining whether a person is regarded as "domiciled in the United Kingdom" for the purposes of this Part.'

${ }^{110}$ Section $47 \mathrm{~B}(11)(\mathrm{b})$.

${ }^{111}$ S47B(8)(a).

112 Detail Tribunal Rules.

${ }^{113}$ http://www.catribunal.org.uk/247-8763/Draft-Tribunal-Rules.html
} 
the relatively sparse legislative text in revised Section 47B in particular to the Tribunal Rules on collective actions, ${ }^{114}$ introduced as part of a broader review of the Tribunal's rules following a formal consultation by the Department for Business, Innovation \& Skills early in 2015. We shall outline the relevant rules and how they may be interpreted, but it must be stressed that, at least in the early years of the new regime, as with all radical legislative changes, experiential learning will be important, not least for the Tribunal itself. The rules on collective actions and settlements are in part $\mathrm{V}$ of the Competition Appeal Tribunal Rules 2015. The relevant certification process provision is set out in Rules 76-78, Rule 78 of which provides as follows:-

'78. (1) The Tribunal may certify claims as eligible for inclusion in collective proceedings where, having regard to all the circumstances, it is satisfied by the proposed class representative that the claims sought to be included in the collective proceedings-

(a) are brought on behalf of an identifiable class of persons;

(b) raise common issues; and

(c) are suitable to be brought in collective proceedings.

Common issues are defined in Rule $72(2)(\mathrm{f})$ as 'the same, similar or related issues of fact or law', reflecting the statutory provision in $\mathrm{s} 47 \mathrm{~B}(6)$. The potential difficulties in this context under the US CPR Rule 23 were demonstrated in Wal-Mart Stores Inc v Dukes. ${ }^{115}$,The application of similar requirements under the English CPR 19.6 in Emerald Supplies demonstrated their potential limitations in a business context, and certainly in relation to hybrid claims involving mid and end-purchasers from the same cartel. ${ }^{116}$ Nonetheless, the new statutory test appears to be wider in scope than the 'same interest' test under CPR 19.6 and in principle many collective claims relating to aggregated end-purchaser/consumer overcharges should satisfy this test relatively easily.

Considerable discretion is afforded the Tribunal in determining the 'suitability' of collective proceedings, and whether they should be opt-in or opt-out, under the criteria set out in Rule 78(2) and (3) respectively, as follows:-

'(2) In determining whether the claims are suitable to be brought in collective proceedings for the purposes of paragraph (1)(c), the Tribunal will take into account all matters it thinks fit, including but not limited to -

(a) whether collective proceedings are an appropriate means for the fair and efficient resolution of the common issues;

(b) the costs and the benefits of continuing the collective proceedings;

(c) whether any separate proceedings making claims of the same or a similar nature have already been commenced by members of the class;

(d) the size and the nature of the class;

(e) whether it is possible to determine for any person whether he is or is not a member of the class;

(f) whether the claims are suitable for an aggregate award of damages; and

\footnotetext{
${ }^{114}$ Detail Tribunal Rules, introduced under new paras. $15(B)$ and $15(C)$ of Schedule 4 to the Enterprise Act 2002.

${ }^{115} 603$ F.3d 571, 630 (9th Cir. 2010).

${ }^{116}$ Emerald may be considered a peculiar case in this context.
} 
(g) the availability of alternative dispute resolution and any other means of resolving the dispute.

(3) In determining whether collective proceedings should be opt-in or opt-out proceedings, the Tribunal will take into account all matters it thinks fit, including but not limited to the following additional matters to those set out in paragraph (2)-

(a) the strength of the claims; and

(b) whether it is practicable for the proceedings to be brought as opt-in collective proceedings, having regard to all the circumstances, including the estimated amount of damages that individual class members may recover.'

It is difficult to predict how these criteria will be applied in practice. In particular, the 'costs and benefits' test does not identify any particular recipients of such costs/benefits, how they will be calculated, and how the Tribunal should evaluate and determine an appropriate trade-off between costs and benefits to different parties- either intra-class or between the class and defendant(s). Furthermore, the incorporation of a 'merits' test under Rule 78 3(a), albeit only for the purpose of determining whether a claim should be opt-in or opt-out, is problematic at the certification stage. ${ }^{117}$ Application of this rule is also likely to favour follow-on actions, although most consumer claims will inevitably fall into this category. As indicated in discussing developments in US class action certification, a stringent certification examination is understandable and necessary in order to balance conflicting aims of the justice system. Nonetheless, where certification involves assessment of the strengths of claims, this may inevitably lead to lengthy, protracted interlocutory disputes, delaying justice and potentially disincentivising claimants from raising collective proceedings.

\section{Incentives I: Who can Claim- The Representative?}

The collective proceedings mechanisms are dependent on the claim being raised by a suitable class representative. However, the potential role for collective proceedings is likely to be greatly determined by the range of parties who may be deemed eligible to be a class representative. In particular, should lawyers/law firms be entitled to act as a representative? This was a key issue throughout the BIS consultation phase and Parliamentary debates on the Consumer Rights Bill. The BIS response in January $2013^{118}$ to its earlier consultation ${ }^{119}$ stressed the following policy decisions had been taken in this context:-

'5.30. Regarding what sort of private parties should be able to bring cases, the Government agrees that there could be a risk of abuse if legal firms, funders or special purpose vehicles established solely for the purpose of litigation were allowed to bring cases. Government believes that only those who have a genuine interest in the case, such as genuinely

\footnotetext{
${ }^{117}$ How do you measure the strength of a claim at the pre-disclosure stage? See Wal-Mart supra.

${ }^{118}$ See 'Private Actions in Competition Law: A consultation on options for reform- government response' Jan 2013 available at https://www.gov.uk/government/uploads/system/uploads/attachment data/file/70185/13501-private-actions-in-competition-law-a-consultation-on-options-for-reform-government-response1.pdf

${ }^{119}$ See BIS 12/742, 'Private Actions in Competition Law: A Consultation on Options For Reform', April 2012.
} 
representative bodies (such as trade associations or consumer associations) or those who have themselves suffered loss should be allowed to bring cases.

5.31. 'For the avoidance of doubt, the Government proposes to abolish the requirement fora list of suitable bodies to be established by the Order of the Secretary of State and to instead rely on the representative's suitability being assessed by the CAT at certification.'

The Government's clear intention was to exclude law firms and special purpose vehicles ('SPVs') from qualifying as a class action representative, but there is neither an express ban in the legislation nor the Tribunal rules, which provide in Rule $77^{120}$ as follows:-

'(2) In determining whether it is just and reasonable for a person to act as the class representative, the Tribunal will consider whether that person-

(a) would fairly and adequately act in the interests of the class members;

(b) does not have, in relation to the common issues for the class members, a material interest that is in conflict with the interests of class members;

(c) (if there is more than one person seeking approval to act as the class representative in respect of the same claims) would be the most suitable person to act as such;

(d) will be able to pay the defendant's recoverable costs if ordered to do so; ${ }^{121}$ and

(e) where an interim injunction is sought, will be able to satisfy any cross-undertaking in damages required by the Tribunal.

77(3) In determining whether the proposed class representative would act fairly and adequately in the interests of the class members for the purposes of paragraph (2)(a), the Tribunal will take into account all the circumstances, including-

(a) whether the proposed class representative is a member of the class, and if so, his suitability to manage the proceedings;

(b) if the proposed class representative is not a member of the class, whether it is a preexisting body and the nature and functions of that body;

(c) whether the proposed class representative has prepared a plan for the collective proceedings that satisfactorily includes-

(i) a method for bringing the proceedings on behalf of represented persons and for notifying represented persons of the progress of the proceedings; and

(ii) a procedure for governance and consultation which takes into account the size and nature of the class; and

(d) any estimate of and/or details of arrangements as to costs, fees or disbursements which the Tribunal orders that the proposed class representative must provide.'

Again there was considerable Parliamentary focus and concern regarding potential exploitation of the new collective mechanisms by the legal profession, exemplified by the following statement:- 'The ban on exemplary damages and damages-based agreements,

\footnotetext{
${ }^{120}$ Note that Rule 77(1) simply restates the statutory provision that a representative need not be a class member but that the class representative will be authorised only if it is just and reasonable to do so.

${ }^{121}$ Note, although we will not deal with costs issues in this paper it is worth simply noting the contrast with the costs rules in the US system and this may continue to work as a major disincentive for class actions in the UK, depending on success probabilities.
} 
while welcome, will not remove the huge incentive for lawyers and litigation funders to make a handsome living out of exploiting these provisions. ${ }^{122}$ There was an attempt to circumscribe the wide discretion of the Tribunal in this context by proposing amendments to the legislation to make express provision to ensure that lawyers, claims management organisations and others, who might gain from the litigation itself, would not be able to satisfy the just and reasonable test. ${ }^{123}$ Nonetheless the Government stressed that the basic provision should be applied by the most suitable body, the Tribunal, with discretion and it would be inappropriate to provide a prescriptive list of bodies suitable to act as a representative body. ${ }^{124}$ It is important to note that although most of the literature, debate and commentary on the reform of collective redress has focused on the specific issue of consumer redress, the Consumer Rights Act provisions here potentially provide for collective mechanisms for businesses and consumers. Indeed, to date, inevitably to some extent reflecting the absence of an appropriate mechanism and incentives for competition claims by groups of consumers, virtually all of the competition litigation in the UK has involved business claimants. The 2015 Act collective mechanisms may allow a number of direct or indirect business purchasers to join their claims together in a more effective way than was previously permitted, ${ }^{125}$ and although not the main driver of these provisions or their key target, this will enhance the deterrent impact of the primary competition legislation whilst also being pro-business in providing compensation to businesses harmed by illegal cartels. Accordingly, the Government rejected an amendment to the Bill which would limit those who could act as class representative to any appropriate consumer representative body or trade association and thereby effectively exclude SME's from bringing forward collective actions. ${ }^{126}$

However, the key issue and dilemma in devising an effective collective actions regime, and for the Tribunal to resolve in dealing with opt-out collective applications in particular, is how to apply the Rule 77 criteria in a way that facilitates and incentivises consumer redress but respects the Parliamentary concerns regarding over-incentivising lawyers. Under US Rule 23, the class representative is always a member of the class but in effect the appointment is nominal and all effective decision-making in a class action is taken by the relevant law firm. Class action settlements, and the relative fee arrangements, consequently require court approval. ${ }^{127}$ A central and as yet unresolved question is whether section 47B will be utilised primarily for class actions led by a class member or as a representative collective mechanism, and consequently what types of organisation may qualify as suitable representatives. ${ }^{128}$ If we reconsider US CPR Rule 23, aside from the prerequisite for commonality, the two key issues in the certification process were typicality and adequate representation. The former is aimed at avoiding a conflict of interests between the named representative and the class members; the latter requires the class action lawyer to be

\footnotetext{
${ }^{122}$ Baroness Noakes, Grand Committee, House of Lords, $3^{\text {rd }}$ November 2014, Col. 575.

123 Ibid.

${ }^{124}$ Baroness Neville-Rolfe, HL Report, $2^{\text {nd }}$ sitting, 24 November 2014 col. 743.

${ }^{125}$ See for instance Emerald Supplies considered supra.

${ }^{126}$ Baroness Neville-Rolfe, HL Committee, Report $2^{\text {nd }}$ sitting, 24 November 2014 col. 743.

127 See R H Lande and J P Davis 'Benefits from private Antitrust enforcement: An Analysis of Forty Cases' (2008) 42 University of San Francisco Law Review 879.

${ }^{128}$ There is a technical argument, which is not supported by authority and is unlikely to be accepted, that as Section $47 \mathrm{~B}(\mathrm{I})$ requires that the class action "combin(es) two or more claims to which section 47A applies", and section 47A reads "A person may make a claim...", this could be interpreted as a standing requirement for someone who is harmed, i.e. the class action needs a lead claimant.
} 
sufficiently qualified, experienced and competent to conduct class action litigation. Rule 77 embodies aspects of both tests and it is unclear at whom the specific criteria in Rule 77 are aimed. Of course the representative may, as expressly provided for in amended S47B and Rule 77, be a class action member alone. There is no typicality requirement as such, as this would exclude the potential for a purely representative action, not led by a class member. However, there are considerable hurdles to be satisfied by a potential class member representative in satisfying the central 'acting fairly and adequately' test:- would an individual consumer claimant be 'suitable' to manage proceedings; able to pay the defendant's recoverable costs if ordered to do so; able to satisfy any cross-undertaking in damages required by the Tribunal. Of course, the latter two are largely dependent on the funding arrangements set in place prior to commencing collective proceedings, as discussed further below. The arrangement of a satisfactory claim management plan could of course be organised by the acting law firm, subject to funding arrangements, but it is uncertain how an individual class action representative can provide a satisfactory procedure for governance of the claim even in respect of an 'identifiable' set of claimants in opt-out collective proceedings, where by its nature, claimants have not (been required to) individually become involved in the proceedings. Effectively, the class representative would have to satisfy tests modelled on the adequacy of representation test under the US model, which are aimed at the competency and expertise of counsel to act in a class action; and would face considerable cost and funding issues as discussed below.

The representative model of collective proceedings, as opposed to the class action member representative, would probably better reflect the intention of BIS in proposing a modernised collective redress mechanism, in order to enhance the prior (opt-in) representative model which had, as outlined, above been of limited value. Only Which? (The Consumers' Association) was entitled to undertake any representative actions under that procedure, whereas the Government preferred the introduction of an open-ended test for the Tribunal to determine suitability as a class representative under the revised collective proceedings rules rather than designating specific bodies competent to act. Nevertheless it was anticipated at all stages of the drafting and progress of the legislation that suitable consumer organisations, such as Which? would be involved in championing consumer rights through this process. However, their involvement would inevitably depend partly on priorities, resources and effective funding mechanisms. This leaves the key issue as to whether other representative options may be available and satisfy the Rule 77 requirements. Indeed, there was considerable debate over the last two years regarding whether law firms and Special purpose vehicles (SPVs) could act as class representatives. Given the absence of a typicality requirement this depends on the assessment of whether those bodies would act 'fairly and adequately', whether there would be any 'conflict of interest' with the class and on the interpretation of the particularly vague consideration in Rule 77 (3)(b) as to whether the representative was 'a pre-existing body and the nature and functions of that body'. Prima facie it would appear that it would be relatively straightforward for law firms to satisfy the first two requirements, based on the normal ethical and professional duties imposed on lawyers but each of these three issues would be more problematic for bodies specially constituted solely to pursue claims with a profit motive.

Nonetheless, and particularly in relation to the issue of law firms as representatives, it is suggested here that any concerns should dissipate when the Tribunal Rules on Collective Proceedings are considered in depth. In addition to the issues already considered, regarding 
certification and the class representative, the Rules provide for: notice of a Collective Proceedings Order in a manner prescribed by the Tribunal; ${ }^{129}$ the class representative to establish a class Register (which may be inspected by the Tribunal and other parties); ${ }^{130}$ the variation, revocation, sist or stay of a Collective Proceedings Order by the Tribunal; ${ }^{131}$ for case-management and disclosure by the Tribunal where necessary; ${ }^{132}$ for notice of any judgment order to be given by the class representative to the represented persons in a form and manner prescribed by the Tribunal; ${ }^{133}$ rules on the assessment of individual damages from an aggregated sum; ${ }^{134}$ the Tribunal to make an Order detailing the requirements for the distribution of an award of damages. ${ }^{135}$ Even more significant are the detailed provisions in relation to an application for a Collective Settlement Approval Order. ${ }^{136}$ This requires details of the terms of the proposed settlement, including provisions on payments of costs and fees; specify how sums are to be paid and distributed and how class members will be notified of the application. The most significant provision requires a statement that the applicant believes the settlement to be fair and reasonable, supported by evidence as to the merits of the settlement. ${ }^{137}$ The Tribunal must determine whether the terms of the proposed settlement are just and reasonable ${ }^{138}$ taking into account a number of factors including (a) the amount and terms of the settlement, including any related provisions as to the payment of costs, fees and disbursements; (b) the number or estimated number of persons likely to be entitled to a share of the settlement; (c) the likelihood of judgment being obtained in the collective proceedings for an amount significantly in excess of the amount of the settlement; (d) the likely duration and cost of the collective proceedings if they proceeded to trial; (e) any opinion by an independent expert and any legal representative of the applicants. ${ }^{139}$ Furthermore, the representative must give notice of the terms of the settlement and its approval to represented persons in a form and manner prescribed by the Tribunal. ${ }^{140}$

Accordingly, although the revised statutory scheme for certification and appointment of a class representative is rather brief, the Tribunal rules provide more 'flesh on the bone' and are aimed at avoiding conflicts of interest and adequacy of representation. Moreover, the Tribunal Rules establish a rigorous pre and post certification appraisal of just and reasonableness, and in particular the detailed case management and Tribunal approval mechanisms for all aspects of its Order-making and Settlement approving processes, should ensure both that defendants are adequately considered and that the interests of the mass opt-out claimants (who do not have a direct input into the court processes and outcomes) are adequately taken into account in achieving a fair and reasonable outcome to the

\footnotetext{
${ }^{129}$ Rule 80.

${ }^{130}$ Rule 82.

${ }^{131}$ Rule 84.

132 Rules 87 and 88.

${ }^{133}$ Rule 90(2).

134 Rule 91.

135 Rule 92.

136 Rule 93- where there has already been a Collective proceedings Order by the Tribunal. Following the discussion above, Rule 94 provides for a Collective Settlement Order where there has been no Collective proceedings Order (mirroring the requirements in Rules 77 and 78), and Rule 95 provides for a Collective Settlement Approval order in that context.

${ }^{137}$ Rule 93(2)(c).

${ }^{138}$ Rule 93(6).

${ }^{139}$ Rule 93(7).

${ }^{140}$ Rule 93(11).
} 
litigation process. The precise nature of the representative should be less significant, provided they can effectively represent the mass represented persons in an opt-out claim. Of course, the nature of the representative, and whether they will be over- or adequately incentivised to pursue this type of litigation, depends greatly on the funding mechanisms available.

\section{Incentives II- Funding}

It has already been emphasised that the availability of contingency fees for lawyers in the USA has been central in incentivising the raising of class actions on behalf of consumers. Class action damages recovery is an integral element of US antitrust enforcement, yet virtually all class actions are settled and those class settlements, including the fee payable to the successful class lawyer, are approved by court. ${ }^{141}$ In the legal systems of the UK, particularly England and Wales, there has been a considerable shift in the use of alternative legal fee arrangements over the last fifteen years. ${ }^{142}$ Conditional fee arrangements, involving a success percentage uplift (of up to 100\%) of a standard fee, are common, albeit following the Jackson Report, ${ }^{143}$ the Legal Aid, Sentencing and Punishment of Offenders Act 2012 (LASPO), has prohibited the recovery of success fees and ATE insurance premiums from the unsuccessful party. Following the introduction of the Damages-Based Agreements Regulations 2013, ${ }^{144}$ damages-based agreements (DBAs), where a lawyer's fee is contingent upon the success of the claim and is calculated as a percentage of the compensation received by the claimant, have been permissible generally in civil cases. The cap is generally set at $50 \%$ of the damages awarded ( $25 \%$ in personal injury cases) but does not affect the defendants' cost liability. The introduction of DBAs generally in English civil procedure sought to incentivise lawyers to pursue more risky and work-intensive cases. Nonetheless, the original BIS consultation raised concerns about the availability of DBAs in conjunction with the new collective proceedings mechanisms. Although these concerns were considered by certain key respondents to be 'misconceived', ${ }^{145}$ and the Jackson Report had specifically identified DBA's as a way of funding collective actions, ${ }^{146}$ the Government's response to the consultation in January $2013^{147}$ stated:-

'5.62. Prohibiting the use of damages-based agreements (DBAs), sometimes called contingency fees, was one of the key safeguards highlighted by many respondents as necessary to ensure that an opt-out collective actions regime did not lead to a 'litigation culture'. The Government agrees that this prohibition would be an important safeguard and that allowing DBAs could encourage speculative litigation, thereby placing unjustified costs

\footnotetext{
${ }^{141}$ See R H Lande and J P Davis ‘Benefits from private Antitrust enforcement: An Analysis of Forty Cases' (2008) 42 University of San Francisco Law Review 879.

142 See generally C.Hodges, J.Peysner and A.Nurse 'Litigation Funding: Status and Issues', Joint Report University of Oxford (Centre for Socio-Legal Studies) \& University of Lincoln (Sponsored by Swiss Re) (2012) and J. Peysner, Access to Justice: A Critical Analysis of Recoverable Conditional Fees and No Win No Fee Funding (Palgrave MacMillan: London, 2014).

143 Review of Civil Litigation costs: Final report, Dec 2009 available at https://www.judiciary.gov.uk/wpcontent/uploads/JCO/Documents/Reports/jackson-final-report-140110.pdf

144 SI 2013/609.

${ }^{145}$ Rachel Mulheron and Vincent Smith. See also the Taylor Report in the Scottish context.

${ }^{146}$ Review of Civil Litigation costs: Final report, Dec 2009 available at https://www.judiciary.gov.uk/wpcontent/uploads/JCO/Documents/Reports/jackson-final-report-140110.pdf.

147 Available at https://www.gov.uk/government/uploads/system/uploads/attachment_data/file/70185/13501-private-actions-in-competition-law-a-consultation-on-options-for-reform-government-response1.pdf
} 
on defendant businesses and creating an incentive for lawyers to focus only on the largest cases.

5.63. The Government has therefore decided to prohibit DBAs in collective actions cases in the CAT. This will require an amendment to the LASPO Act 2012 for this new type of case.'

S47C(8) of the amended Competition Act 1998 provides statutory expression to the Government's intention by providing that ' a damages-based agreement is unenforceable if it relates to opt-out collective proceedings' ${ }^{148}$ Hviid and Peysner have considered the incentives necessary for increased private enforcement activity:- they stressed that any optout system would also benefit from the availability of contingency fees ${ }^{149}$ and an increase in potential damages awards (for instance treble or exemplary damages) to increase the value of the prospective 'prize' for both claimants and their lawyers. ${ }^{150}$ Accordingly, a central conundrum to resolve is how prospective opt-out collective proceedings can be financed. Where the class representative is a consumer organisation, it could decide to underwrite the costs and liabilities of the proceedings, but inevitably there will be difficult decisions about the risks of involvement (notably costs), and the appropriate focus and prioritisation of their scarce resources by such bodies, which may limit the range of their activity. In relation to an actual class claimant representative, unless they were a wealthy, benevolent class member who could subsidise the action, what are the options? Prima facie, the fact that a DBA agreement is unenforceable would not appear to restrict the freedom of a potential representative to enter such an agreement, provided the matter of the fees is not litigated. ${ }^{151}$ However, at the stage when a fee arrangement would be agreed, the Tribunal would not as yet have certified the proceedings or authorised the representative, and accordingly any lawyer would be taking a risk in acting on this basis. Moreover, given the Tribunal powers under the Rules to approve all Collective Proceedings Settlements including fees, the unenforceability of any such DBA would inevitably be confirmed at that stage of the process. In the absence of a DBA incentive, law firms are unlikely to subsidise the interim costs of an action plus the risks of a costs award for an unsuccessful claim in favour of the defendant. After the Event Insurance has been utilised in B2B competition law claims, but would require a claimant ${ }^{152}$ to pay any premiums in advance. Given that LASPO 2012 prevents the recovery of success fees and ATE premiums from a losing defendant, lawyers would need to be confident that the Tribunal would authorise the payment of those costs from under Tribunal Rule 93(7). ${ }^{153}$

\footnotetext{
${ }^{148}$ Amending s58AA of the Courts and Legal Services Act 1990. See R. Mulheron 'The Damages-Based Agreements Regulations 2013: Some Conundrums in the "Brave New World" of Funding' (2013) 32 Civil Justice Quarterly 241-255.

${ }^{149}$ Or a Contingency Legal Aid Fund:- See Riley and Peysner 'Damages in EC Antitrust Actions: Who Pays the Piper?' (2006) European Law Review pp 748-761. See generally C.Hodges, J.Peysner and A.Nurse 'Litigation Funding: Status and Issues', Joint Report University of Oxford (Centre for Socio-Legal Studies) \& University of Lincoln (Sponsored by Swiss Re) (2012); J. Peysner, Access to Justice: A Critical Analysis of Recoverable Conditional Fees and No Win No Fee Funding (Palgrave MacMillan: London, 2014).

150 See M Hviid and J Peysner 'Comparing Economic Incentives Across EU Member States' Chapter 6 in Rodger (ed) 2014 supra.

${ }^{151}$ In practice a law firm is unlikely to undertake the risk of acting on this basis.

152 It is unlikely that a law firm would pay the ATE premium.

${ }^{153}$ In relation to a Collective Settlement, or under Rules 92(4) and (5) in a damages award from the unclaimed damages pot.
} 
The uncertainty on cost recovery suggests a potentially crucial role, particularly in relation to class claimant representative actions, for external investment in the form of Third Party Funding. ${ }^{154}$ There was an attempt to amend the legislation in Parliament to exclude such third party litigation funding agreements. ${ }^{155}$ However this straight-jacketing attempt was excluded by the Government as it accepted that third party funding may be necessary to ensure effective consumer redress where a representative claimant did not have a sufficient reserve of funds or could not persuade a law firm to act effectively pro bono. Indeed, this issue reflects the ambivalent approach of the Government, which sought to encourage effective consumer redress but was simultaneously conscious of the misapprehensions and misconceptions regarding the introduction of a US style funding and litigation cultures. The Government stressed during the passage of the Bill that blocking access to third party funding would unnecessarily constrain competition law private enforcement by limiting access to larger businesses and discouraging bodies organisations such as Which? from fully participating as a lead representative organisation. ${ }^{156}$ Similarly, third party funding could be provided where a law firm seeks to act as the representative, although this would be highly risky given the uncertainty regarding the application of the suitable representative criteria as set out in the Tribunal rules. Will third party funding be a viable option for class claimant representative actions? Would a third party funder engage directly with a class representative to determine the appropriate return on their investment? This return could be set at a similar level and basis as a damages-based agreement, but such damages related returns may not be approved by the Tribunal under Rule 93(7) in its determination of fees and disbursements to be met. The considerable uncertainty may disincentivise third party funders from involvement, although this may change in the light of practice, damages awards and Settlement Approvals by the Tribunal over a period of time.

There are two further issues which may act as disincentives or discourage appropriate funding arrangements and thereby risk the success of the new collective proceedings mechanisms.

The first is the potential impact of the applicability of settlement offers by defendants in the context of collective proceedings. The Rules on Settlement Offers are set out in Tribunal Rules 44-48, and essentially they replicate the cost consequences under CPR Rule 36 offers, ie defendants will not be liable for costs after the settlement offer by the defendant(s) if the final award is below the level of the settlement offer. The Government's final consultation on the draft Tribunal Rules recommended the exclusion of settlement offers from the optout collective action mechanism, ${ }^{157}$ primarily on the basis that it may incentivise the

\footnotetext{
154 In Arkin v Borchard Lines ([2005] EWCA Civ. 655), the claimant had been unsuccessful in an Article [101] action, for which a third party funder had underwritten the litigation in exchange for $25 \%$ of the first $f 5$ million and $23 \%$ of any excess should the claim be successful. At first instance, the defendants were unsuccessful in a costs application but this was partly overturned by the Court of Appeal, which limited the potential costs liability of a third party-funder on a 'pound for pound' basis- see Peysner, J, 'After Sub-Prime' [2008] Civil Justice Quarterly 407. For a broader discussion of third party funding, see R Mulheron, 'Third Party Funding of Litigation: A Changing Landscape' (2008) 27 Civil Justice Quarterly 312-341 and 'England's Unique Approach to the Self-Regulation of Third Party Funding: A Critical Analysis of Recent Developments' (2014) 73(3) Cambridge Law Journal 570-597.

Though note Hodges' scepticism regarding whether such claims would be attractive to litigation funders:- $\mathrm{C}$ Hodges ‘Fast, Effective and Low Cost Redress: How Do Public and Private Enforcement and ADR Compare?' , Ch 8 in Rodger (ed) 2014 supra.

${ }^{155}$ Baroness Noakes, Grand Committee, House of Lords, Report, $3^{\text {rd }}$ November 2014, Col. 575.

${ }^{156}$ Baroness Neville-Rolfe, HL Committee, House of Lords, $3^{\text {rd }}$ November 2014 at 582.

${ }^{157}$ https://www.gov.uk/government/consultations/competition-appeal-tribunal-rules-of-procedure-review
} 
defendant to make a low settlement offer. This is not a particularly convincing argument per se, as it could apply generally to such settlement offers. However, the exclusion of settlement offers from the new collective proceedings regime should be supported on the basis that its introduction may unnecessarily shift the bargaining power in the litigation process away from the consumer to the business defendant, contrary to the underlying rationale in the introduction of the revised collective redress mechanism. More importantly, the introduction of general settlement offers would have important potential implications for the cost and funding cover of the litigation by the claimants- in particular the availability of settlement offers may prejudice the position of the class representative in making funding arrangements ex ante, because of the risk of a low settlement offer which may not cover costs or the risk of a subsequent lower award of damages which would then not include costs and jeopardise the claim and the funder. The statutory system of Collective Settlement, with Tribunal involvement in approving a settlement, provides a comprehensive solution, allows for the interests of all relevant parties and the underlying benefit of an effective collective proceedings mechanism to be taken into account. It is important that this system should not be short-circuited by a settlements offer process which is not appropriate in this consumer-focused context.

The second is that section $47 \mathrm{C}(1)$ of the Competition Act prescribes the award of exemplary damages by the Tribunal in collective proceedings. Exemplary damages may potentially be awarded in a competition law damages claim, ${ }^{158}$ and their availability would certainly incentivise claimants and funders. However, this exclusion is not considered to be particularly significant given the limited circumstances in which such damages may be awardable, and consequently the general reticence of the English courts to make such damages awards in any event. ${ }^{159}$

On the other hand, one option to help to fund opt-out cases- albeit ex post facto- would be to use unclaimed damages to cover all or part of a claimant's costs, which could include any success fee agreed with a legal representative and any insurance taken out. The US has a developed cy pres award scheme ${ }^{160}$ and the Consumer Rights Act provides for unclaimed damages by represented persons in opt-out proceedings to be awarded to the Access to Justice Foundation. ${ }^{161}$ However the Act contains provision for the costs or expenses incurred by the class representative in connection with the proceedings to be paid to the representative by Order of the Tribunal. ${ }^{162}$ It is imperative that consumers should be the beneficiaries of redress, and that provision means mean that legal costs can be recovered

\footnotetext{
${ }^{158}$ See for example the ECJ ruling in Case C-295/04 Manfredi v Lloyd Adriatico Assicurazioni SpA, [2006] ECR I66i9; and the CAT judgment in 2 Travel Group plc (in liquidation) v Cardiff City Transport Services [2012] CAT
} 19.

\footnotetext{
${ }^{159}$ See 2 Travel Group plc (in liquidation) v Cardiff City Transport Services [2012] CAT 19, but note the earlier Court of Appeal ruling in Devenish Nutrition Itd v Sanofi-Aventis SA [2008] EWCA Civ 1086.

160 See the discussion about cy pres damages in J Peysner and A Riley 'Damages in EC Antitrust Actions: Who Pays the Piper?' (2006) European Law Review, 748-761.

${ }^{161}$ Created by the Legal Services Act 2007. S47C (5) of the amended Competition Act 1998 provides:- 'Subject to subsection (6), where the Tribunal makes an award of damages in opt-out collective proceedings, any damages not claimed by the represented persons within a specified period must be paid to the charity for the time being prescribed by order made by the Lord Chancellor under section 194(8) of the Legal Services Act 2007.' Subsection 7 allows for another charity to be substituted for the AJF by Order of the Secretary of State/

${ }^{162}$ Section 47C(6) of the Competition Act 1998.
} 
only after consumers have claimed their redress. ${ }^{163}$ Accordingly, the CAT can consider the suitability of a representative's costs and funding arrangements in applying Tribunal Rule 92(4) which provides as follows:- 'Where the Tribunal is notified that there are undistributed damages pursuant to paragraph (3)(b), it may make an order directing that all or part of any undistributed damages is paid to the class representative in respect of all or part of any costs, fees or disbursements incurred by him in connection with the collective proceedings.' However, it is notable that there is no statutory provision regarding the unclaimed pot of compensation in relation to Collective Settlements. As opt-out Collective Proceedings are often likely to be resolved by Collective Settlement Approval Orders ${ }^{164}$ (or if available settlement offers) this may mean that the laudable aim of benefitting the charitable Access to Justice Foundation is not achieved. The relevant Tribunal Rule in relation to a Collective settlement Order, Rule 93(7) merely provides that in determining if the terms of a proposed Collective settlement are fair and reasonable, the Tribunal shall take into account all the circumstances, in particular ' $(\mathrm{g})$ the provisions regarding the disposition of any unclaimed balance of the settlement.' Distribution to the defendant is not precluded by this provision, and it will be interesting to note whether in practice the Tribunal will make any additional requirements such as payment to the AJF.

\section{Concluding Remarks}

Schedule 8 of the Consumers Rights Act introduces various measures to facilitate and encourage competition litigation in the UK, ${ }^{165}$ and a key aspect, discussed in this article, is the legislative revision of the Competition Act 1998 to allow for opt-out collective proceedings (before the CAT) in the UK. This is a potentially significant innovation which may help to enhance consumer redress in respect of competition law infringements ${ }^{166}$ whilst also increasing the deterrent effect of the competition rules. However, this article has demonstrated that a combination of the (sparse) statutory rules and (more detailed) Tribunal Rules on Collective Proceedings may limit the effectiveness of the new opt-out mechanism for consumer redress. There is uncertainty regarding the likely application by the Tribunal of the relevant provisions and Rules regarding certification and authorisation of the class (settlement) representative, although the Tribunal's approach to these issues should become clearer with practice. Generally there have been ambiguous messages as to whether collective proceedings are primarily designed for class actions represented by a class claimant or by a representative body. Funding is also central to the effectiveness of an opt-out model. In particular, the need for effective management of claims would suggest that any body, including a collective claim SPV with suitable governance and decisionmaking should qualify as a suitable class representative. In this context it is unclear, and certainly not supported by empirical evidence, why there was such concern throughout the consultation and Parliamentary processes regarding over-incentivised claims. It is argued

\footnotetext{
${ }^{163}$ See Jenny Willott, Hansard, HC, Committee Debate, $11^{\text {th }}$ March 2014, col. 588.

${ }^{164}$ Note that collective Settlements may be sought even where there is no CPO.

${ }^{165}$ See A Andreangeli, 'The Changing structure of competition enforcement in the UK: The Competition Appeal Tribunal between present challenges and an uncertain future' (2015) 3(1) JAE 1-30.

${ }^{166}$ Although there is scepticism about the extent to which 'enhanced' private enforcement mechanisms will most effectively deliver compliance and redress:- see for instance C Hodges 'Fast, Effective and Low Cost Redress: How Do Public and Private Enforcement and ADR Compare?' , Ch 8 in Rodger (ed) 2014 supra and M loannidou, 'Enhancing the consumer's role in EU private competition law enforcement: a normative and practical approach' [2012] 8(1) Comp. L. Rev. 59-85. See also See C Hodges and R Money-Kyrle 'Safeguards in Collective Actions' (2012) 19(4) Maastricht Journal of International and Comparative Law 477-504.
} 
that the ban on Damages-Based Agreements, combined with the non-recovery of ATE and success fees under LASPO, may make it exceptionally difficult to fund an opt-out claim, particularly where third party funders would require to fund the pre-certification processgiven the uncertainties identified. I would argue that there is a considerable incentivisation problem $^{167}$ which has been driven during the debate by an irrational fear that contingency fees/DBAs would lead to excessive litigation and disproportionate gains for lawyers. These restrictions and uncertainties may inadvertently result in the collective proceedings mechanism being used primarily for common claims by businesses rather than consumers. It is also anticipated that many proceedings will result in Collective Settlement Proceedings using the new voluntary settlement mechanism rather than final judgment. However it is unfortunate that there are no statutory or Tribunal rule provisions for $A D R,{ }^{168}$ as earlier advocated in the BIS Consultation Documents in 2012 and 2013; and that the provisions on unclaimed compensation in Settlements are not parallel with those in damages awards. Nonetheless, the Tribunal supervisory role in statutory Settlement Proceedings is sufficient rationale to exclude normal settlement offers and their implications from the new statutory framework. More generally, it is clear that the US class action has been a central pillar of antitrust enforcement in the US and has demonstrated considerable success in ensuring consumer redress for antitrust infringements. This is predominately due to a combination of the opt-out class action, the availability of contingency fees and judicial case management and control of the settlement outcomes, including lawyers' fees. It is argued that instead of Parliamentary (and wider) focus on irrational fears about the consequences of introducing a US style class action regime and over-incentivising lawyers, greater trust should have been placed in the Tribunal in the exercise of its supervisory role under the revised Tribunal Rules in relation to all aspects of the Collective Proceedings and Settlements regime.

\footnotetext{
167 See M Hviid and J Peysner 'Comparing Economic Incentives Across EU Member States' Chapter 6 in Rodger (ed) 2014 supra.

${ }^{168}$ See C Hodges 'Fast, Effective and Low Cost Redress: How Do Public and Private Enforcement and ADR Compare?', Ch 8 in Rodger (ed) 2014 supra.
} 